\title{
G.B.SHAW'S SAINT JOAN - A DIALOGUE BETWEEN THE ANCIENT AND THE MODERN WORLDS
}

\author{
Dr. Parneet Jaggi \\ Associate Professor in English, \\ Dr. B. R. Ambedkar Government College, \\ Sri Ganganagar (Raj.)
}

Article DOI: https://doi.org/10.36713/epra5578

\begin{abstract}
My paper attempts to peruse Joan's religious fanaticism, reaching us through the perspective of 600 years and then filtered through Shaw's imagination, becoming the protest of a plain-spoken individual conscience. "What other judgment can I judge by but my own?" The events presented constitute the birth of the great changes that would hit the middle-aged Europe in the forthcoming decades. Indeed, if one adopts a post-colonial stance, it is quite possible to see Joan as a champion not only of Nationalism, but also of anti-colonialism. We are shown Joan's posthumous rehabilitation as an example of a modern show trial, and her original court hearing as one of history's terrible state trials. In Shaw's view Joan was, like Jesus, an agent for change, a change within the established church. When Cauchon, the Bishop of Beauvais, cries out: "Must then a Christ perish in torment in every age to save those who have no imagination?" this connection is made plain, and Joan herself endorses it when she tells the court: "I am His Child, and you are not fit that I should live among you." So Saint Joan becomes Shaw's passion play and represents Joan's life as another coming of Christ to our world.

KEYWORDS: Fanaticism, nationalism, Saint Joan, torment, trial.
\end{abstract}

\section{INTRODUCTION}

The character of Saint Joan has been a source of inspiration for many writers. Besides Schiller and Shaw, she became a central figure in the works of Shakespeare, Voltaire and Mark Twain. The unique power of Shaw's Saint Joan arises from its emphasis on factors which seem to conflict with the legend of a saint, yet under grid the legend by giving it a fresh, contentious, and broad context. Shaw subjects mysticism to rationalism, heroism to skepticism, villainy to understanding, and sanctity to humor, piercing traditional stereotypes with an unrelenting scrutiny. The myth emerges with a new energy and strength, having been rendered both credible and poignant on grounds which appeal to the modern imagination. Charles Berst comments, "The tale of Joan is vividly presented, but more intriguing is Shaw's penetrating conceptualization of the intrinsic nature of Joan, of the complex society in which she lived, and of their nearly epic inter- relationship. While qualifying the supernatural with the human, Shaw links the human to great abstractions. He thereby vitalizes both myth and history with a twofold thrust, rendering them movingly alive through convincing human denominators and memorably significant through timeless social and spiritual implications"(Berst 73).

Saint Joan offers a wide range of aspects open to interpretation. Apart from the historical picture of her person and the circumstances of her time, Shaw manages to interlace his own ideas on progress, nationalism and religion into the character of Joan. In order to understand the character Joan of Arc, it is inevitable to take a closer look at the political situation of France at the end of the $14^{\text {th }}$ and beginning of the 15 th centuries. The major focus at that time was the conflict between England and France, which were at war intermittently between 1337 and 1453 based on the fact that Edward III of England and later Henry V lay claim to the French throne. It was in 1428 that the English forces occupied the northern part of France and 
lay siege to Orleans. At this point the young country girl Joan of Arc arrived on the scene and took a major role in lifting the siege by leading the Dauphin's troops to Orleans. Born around 1412 in the village of Domremy she started hearing voices at an early age of thirteen, voices and visions of St. Michael, St. Catherine and St. Margaret. In May 1428 these voices led her to the king of France to help him recover his kingdom. After lifting the siege of Orleans, which proved a crucial turning point for the French forces, further significant victories followed. In July 1429 Joan was invited to attend the coronation of Charles VII at Rheims Cathedral. It was in May 1430 that she was captured by Burgundian soldiers and handed over to the Bishop of Beauvais. The trial took place at Rouen at the end of March 1431. After Joan had changed the initial declaration that she repudiated her heresies, she was condemned to death and burned at the stake on May 30, 1431. 25 years later, the Pope annulled the sentence passed on her and she was exonerated of all guilt. In 1920 she was ultimately canonized by Pope Benedict XV. We are shown Joan's posthumous rehabilitation as an example of a modern show trial, and her original court hearing as one of history's terrible state trials. Perhaps Shaw had a sense of what was soon to happen in Hitler's Germany. He believed that when a country fell too far behindhand with its political institutions you were likely to get dictatorships, and when you get dictatorships you will get secret tribunals dealing with sedition and political heresy - like the Inquisition.

The established Church, the Catholic Church, was the supreme authority in religious matters and even kings and princes dared not go against its dictates. The Holy Inquisition had the sole jurisdiction over religious offences and not even the King could dare to question its judgement. The belief in witcheraft and magic was widespread and the burning of witches was an everyday phenomenon. However in the early $15^{\text {th }}$ century the Church was engaged in a life and death struggle against the rising tide of Protestantism. Huss in Central Europe and Wycliffe in England had already thundered against the authority of the Church, and Martin Luther was soon to be born.

In Shaw's view, Joan was, like Jesus, an agent for change - change within the established church. When Cauchon, the Bishop of Beauvais, cries out: "Must then a Christ perish in torment in every age to save those who have no imagination?" this connection is made plain, and Joan herself endorses it when she tells the court: "I am His Child, and you are not fit that I should live among you." She, with her individual judgement and inspiration, comes into a headlong clash with this all-powerful organization. She represents a force greater than herself, she is guided by a power vaster than her individual self. She has firm faith in her visions and voices.

Joan's religious fanaticism, reaching us through the perspective of 600 years and then filtered through Shaw's imagination, becomes the protest of a plainspoken individual conscience. "What other judgment can I judge by but my own?" she asks. Shaw presents her to us as an evolutionary force all of whose miracles, though capable of natural explanation, are allowed to trail as legends in the wake of her miraculous personality. In the staging of this 15th-century campaign he translated his own assertion of style into Joan's inspired efficiency of action. But Saint Joan is a tragedy without villains, for everyone, in some way or another, believes he or she is acting for the good. The tragedy lies in human nature itself, which involves us all. Holroyd says that "The epilogue gives Shaw the chance to step forward and talk the play over with the audience. What he tells us is that we too would burn Joan at the stake if we got the chance. It is a sombre message, and Shaw has been attacked for it. For this, out of more than 50 plays, is his only tragedy"( Holroyd 18).

Shaw wrote St Joan in 1923, three years after her canonization by the Catholic Church. In this opus Joan is the receptive individual which the Shavian Life Force needs in order to shape history-in fact, Shaw considers Joan as the first Nationalist and the first Protestant the world has ever known. Still, as many great leaders, according to Shaw Joan was not fully aware of her historical role. The prevailing structures in the middle-aged religious and social framework were Catholicism and feudalism. In the Shavian view, Joan was repudiating both such structures. Joan's divine mission to crown the Dauphin as King of France is seen as an affirmation of national pride-which cuts across class divisions. On the other hand, Joan is regarded as the first protestant in as much as she rejected the institutional authority of the Church. In fact, her refusal to allow priests to mediate between her and the divine would form the core of Protestantism.

An important historical breakthrough in St Joan is the legitimating of double standards. The same action, even if recognized as objectively wrong, unethical, immoral or discriminating at a given historical moment like the present time-can be pious and deemed as correct at another historical moment-the Middle Ages. According to Shaw, individuals cannot be judged as pious or corrupted if not considered and analyzed altogether with the historical moment they live in. Their actions alone are insufficient for such task. This 
legitimation of double standards allows Shaw to defend Bishop Peter Cauchon - the judge who condemned Joan D'Arc to death for heresy and witchery-against charges of corruption raised by the 20th century scholars. Shaw argues that the judge's decision was conform to the values of his time, expression of the middle-aged culture. Even though absurd for the modern man, those values were meant to produce order and meet the needs of the era they were introduced, i.e., Middle Ages.

In the conclusion, Joan d'Arc is presented as a practical women, a harbinger of radical change who was condemned not by the vices of her time but its virtues as personified by Bishop Cauchon. The drama is not to be seen as a fight between good and evil. The events presented constitute the birth of the great changes that would hit the middle-aged Europe in the forthcoming decades.

For Shaw, a mere presentation of the given facts, with whatever dramatic dexterity it might be carried out, was not enough. What he does in the play is to give his interpretation of Joan's story; this is in fact what each of the authors dealing with the theme before him had done in his or her own way, but by the course of history Shaw was privileged over the previous writers dealing with Saint Joan in two ways: he had access to the "historical truth" through Quicherat's documents. He studied minutely the complete and authentic records of Joan's trial through the scholarly translation of $\mathrm{T}$. Douglas Murray published in 1902 and Joan's canonization in 1920 opened an additional perspective from which her story could be viewed. Though this act was in principle only a perfection of the 1456 rehabilitation process, such intensive interest in her person nearly half a millennium after her time and the symbolical significance of proclaiming Joan a saint, offered Shaw an opportunity to give his opinion not only on the story of Joan's life and death but on modern history in general.

Shaw held that history was "an indispensable part of the education of a citizen" (Shaw 180). But he was grossly dissatisfied with the way history was taught at schools. He proclaimed to have derived his knowledge and consciousness of history from the works of Shakespeare, Scott, Dickens, Dumas and others - i.e. from artistically transformed interpretations of history, and he hoped that his own plays would serve next generations in a similar way.

Through history comes the value of learning, through learning come lessons and through lessons come the applicable knowledge to the present. In Bernard Shaw's Saint Joan, the modern world can adapt to three main lessons. The first one being that a single person can make a big difference. Another lesson would be to achieve your goals no matter the boundaries set by the world, finally, one of the important character traits, loyalty. By discovering these lessons and applying it to the contemporary world, we can make an evolution to create a flourishing existence. "The wind has changed. God has spoken. You command the king's army. I am your soldier." Joan has created an influence and a belief that she has changed the winds of fate with the help of God, and turned over a victory to France. To look over Joan's devotion to her hard work, she has accomplished what most say is a miracle beyond belief.

With his keen understanding, Shaw has discerned that the tragic story of Joan would be devoid of meaning altogether if it is read as one in which an innocent "Lamb" is slaughtered by evil 'butchers.' Instead, he presents Cauchon, the Bishop of Beauvais, the Inquisitor and all those with them in the long drawn-out sham of a trial as fools who act out of ignorance born of self-importance or pride. They are all, as Joan comments penetratingly in the Epilogue, "as honest a lot of poor fools as ever burned their betters." In terms of Plato's myth, they are prisoners who are so caught up with and certain of the shadows on the wall of their cave that they simply cannot see the Light, even when it comes down to them from above.

This is supported by a point discussed by Shaw himself in his lengthy Preface. He argues that inborn genius provokes fear and hate, whereas shallow abilities, especially in the realm or military leadership and politics, are welcomed and even praised. We readily reward and elevate the soldiers, while we gladly get rid of the rare seers and the saints in our midst. Or as Shaw says more pithily, "it is far more dangerous to be a saint than to be a conqueror". In a way the play is a record of what mankind does to its geniuses and saints. Man wants neither. This remarkable saintsoldier who lived as God told her, yet a simple maid, who delivered her country from confusion, claiming nothing for herself, who was a leader of the men, yet no more than a girl, is taken as an example of how the chief instruments of human society, the state and the Church combine in natural hatred to crush goodness, purity and the voice of truth.

\section{CONCLUSION}

The art of Shaw is discernible in the universal significance that he has imparted to the martyrdom of Joan. She is viewed as representing forces of revoltProtestantism and Nationalism against the established Church and the Feudal order. Warwick stands for the feudal order and Bishop Cauchon for the Catholic Church. Thus particular is generalized. The Epilogue 
further suggests that there is no end to the struggle in which Joan was engaged. There is no cessation in the march of the Evolutionary will, it enters into a new phase as one generation succeeds another.

With Saint Joan (1924), his masterpiece, Shaw was again accepted by the post-war public and was also the recipient of the prestigious Nobel prize. Now he was regarded as a second Shakespeare, who had revolutionized the British theatre. I conclude with a quote by Raymond Williams, "Shaw has redeemed and embellished our fantasies, and we are properly grateful. But for how long, how long?"(Williams 152).

\section{REFERENCES}

1. Charles A. Berst, "Saint Joan: Spiritual Epic as Tragicomedy," George Bernard Shaw's Saint Joan ,ed. Harold Bloom. New York: Chelsea House, 1987.

2. Michael Holroyd, "A Tragedy without Villains," The Guardian, Saturday 14 July, 2007.

3. George Bernard Shaw, Everybody's Political What's What (London, 1950) 180.

4. Raymond Williams, Drama from Ibsen to Eliot ( London: Chatto \& Windus, 1952) 152.

5. All excerpts of the play have been taken from the text of the play Saint Joan: A Chronicle Play In Six Scenes And An Epilogue (1924) available at http:// gutenberg. net. all/ licence . html. eBook No.: 0200811h.html. First posted: October 2002 